\title{
Raynaud's phenomenon in the occupational context
}

\author{
(D) Rafael Alves Cordeiro ${ }^{1}$ \\ (D) Rogério Muniz de Andrade ${ }^{1}$
}

1. Divisão de Medicina Ocupacional, Instituto Oscar Freire, Faculdade de Medicina da Universidade de São Paulo (USP), São Paulo, SP, Brasil.

http://dx.doi.org/10.1590/1806-9282.65.10.1314

\section{SUMMARY}

OBJECTIVE: To review articles that evaluated the prevalence of Raynaud's phenomenon of occupational origin.

METHODS: The search for articles was carried out in the Medline (via PubMed), Embase, Web of Science, Scientific Electronic Library Online (SciELO), and Latin America and Caribbean Health Sciences Literature (Lilacs) databases.

RESULTS: 64 articles were obtained from the electronic search; 18 articles met the eligibility criteria. All studies discussed the exposure to vibrations in the upper limbs. In 6 of them, the thermal issue was directly or indirectly addressed. No studies have addressed exposure to vinyl chloride.

CONCLUSION: In general, a higher prevalence of Raynaud's phenomenon was found among vibratory tool operators compared to non-exposed workers, with an increase in the number of cases the higher the level of vibration and the time of exposure. Cold is a triggering and aggravating factor of the Raynaud phenomenon and seems to play an important role in the emergence of vascular manifestations of the hand-arm vibration syndrome.

KEYWORDS: Raynaud Disease. Peripheral Vascular Diseases. Vibration. Vinyl chloride. Cold Temperature.

\section{INTRODUCTION}

\section{Raynaud's Phenomenon: General Concepts}

Raynaud's phenomenon is a condition characterized by an exaggerated vasospastic response at the level of the digital arteries and cutaneous arterioles. The episodes are evidenced by a well-marked alteration of the coloration of the fingers, which may be accompanied by paresthesias and pain. The classic triad described for Raynaud's phenomenon is the sequential alteration of white, blue, and red colors'. This triad may not be observed in all patients, and most authors suggest the need for at least pallor and cyanosis to characterize the episode ${ }^{2}$.

In the primary Raynaud's phenomenon, blood vessels are structurally normal and no trophic changes, pittings, digital ulcers, and gangrene are expected. Patients who manifest vasospastic episodes due to a condition or disease that interferes with the mechanisms of vascular reactivity have secondary Raynaud's phenomenon'. Several conditions may be associated with this type of Raynaud's phenomenon, such as autoimmune rheumatic diseases, hematological diseases, endocrine diseases, medications (bleomycin, cisplatin, interferon), malignancies, and situations related to the occupational context ${ }^{1,3}$.

According to the list of work-related diseases, adopt- 
ed as a reference by the Brazilian Ministry of Health, localized vibrations, vinyl chloride, and work in low temperatures are considered etiological agents or occupational risk factors for Raynaud's phenomenon ${ }^{4}$.

\section{Vibrations and Raynaud's phenomenon}

There are two forms of occupational exposure to vibrations: localized and full-body vibration. Localized vibration is transmitted to the hands and arms and can cause injury to the upper limbs, including Raynaud's phenomenon. On the other hand, wholebody vibration can be harmful to the spine ${ }^{5}$.

Raynaud's phenomenon, digital neuropathy, and carpal tunnel syndrome have a well-established occupational link with exposure to localized vibrations. The injuries of the upper limbs associated with this type of exposure are called "hand-arm vibration syndrome". In this syndrome, neurosensory changes and vasospastic disease may coexist or progress independently. Vascular symptoms tend to improve at variable times after withdrawal from exposure. However, advanced cases of digital neuropathy, with loss of hand functions, are usually irreversible ${ }^{5}$.

Occupational exposure to localized vibrations is mainly related to activities using motorized tools such as hammers, crushers, polishers, sanders, drills, lawnmowers, countersinks, and chainsaws. Exposure commonly occurs in heavy construction and civil engineering services but may be present in a variety of activities . $^{5}$

\section{Vinyl chloride and Raynaud's phenomenon}

Vinyl chloride is a volatile substance that is quickly absorbed through the lungs and metabolized by the liver. The final product of the polymerization of vinyl chloride is the polyvinyl chloride (PVC), which is widely used in the plastic industry ${ }^{6}$.

Before the 1970s, workers were commonly exposed to high concentrations of vinyl chloride in occupational air. For this reason, the term "vinyl chloride disease" was used to describe cases of acrosteolysis, hepatopathy, neuropathy, thrombocytopenia, skin lesions, and vascular alterations (Raynaud's phenomenon) attributed to the occupational exposure to this substance. However, industries progressively reduced workers' exposure to vinyl chloride as its deleterious effects and close connection to the onset of cancer were recognized $^{6}$. Since 1979, vinyl chloride has been considered by the International Agency for Research on Cancer (IARC) as a human carcinogen (Group 1) ${ }^{7}$.

\section{Cold environment and Raynaud's phenomenon}

Concerning the work at low temperatures, it is known that cold is a triggering and aggravating factor of Raynaud's phenomenons of any etiology. Individuals with Raynaud's phenomenon are at increased risk of developing frostbite when exposed to low temperatures. Similarly, after frostbite, the affected limb may remain sensitive to cold, manifesting Raynaud's phenomenon $^{3,4}$. Thus, avoiding exposure to cold is an essential measure for the management of Raynaud's phenomenon in all patients ${ }^{1}$.

\section{Rationale and objective}

The determination of occupational exposures is an essential element in the investigation of all patients with Raynaud's phenomenon. Therefore, it is important to know the prevalence of Raynaud's phenomenon in workers exposed to occupational risk conditions. On the face of it, the objective of this study was to conduct a review of articles that evaluated the prevalence of Raynaud's phenomenon of occupational origin, with emphasis on exposure to localized vibrations, vinyl chloride, and work in low temperatures.

\section{METHODS}

Eligibility criteria

Observational studies investigating the prevalence of Raynaud's phenomenon in workers with exposure to localized vibration, vinyl chloride, or low temperatures were considered eligible. Articles published since 1998 in English, Spanish, or Portuguese were searched. We excluded articles about occupational risk factors for the development of autoimmune rheumatic diseases with secondary Raynaud's phenomenon.

\section{SEARCH STRATEGY}

The search for articles was carried out in the following databases: Medline (via PubMed), Embase, Web of Science, Scientific Electronic Library Online (SciELO), and Latin America and Caribbean Health Sciences Literature (Lilacs).

The search strategy for Medline (via PubMed) was "raynaud disease"[All Fields] AND ("epidemiology"[Subheading] OR “epidemiology”[All Fields] OR "prevalence”[All Fields] OR "prevalence”[MeSH 
Terms]) AND (“occupational exposure"[All Fields] OR “occupational diseases"[All Fields] OR “occupational injuries"[All Fields]) AND ("cold temperature"[All Fields] OR ("vibration”[MeSH Terms] OR "vibration"[All Fields]) OR "vinyl chloride"[All Fields]) AND (English[lang] OR Portuguese[lang] OR Spanish[lang]) AND (“1998/01/01”[PDAT] : “2018/01/31”[PDAT]).

This strategy was adapted to the other databases.

The searches were conducted from September 2017 to January 2018.

\section{Selection of articles and data extraction}

The studies were selected in two steps. The first step involved the screening of studies based on titles and abstracts. For the following evaluation, the full texts of the selected articles were retrieved. Information was recorded on: title, authors name, year of publication, country of origin, type of study, characteristics of subjects, occupation, type of exposure, type of evaluation and prevalence of Raynaud's phenomenon.

\section{RESULTS}

We obtained 64 articles from the electronic search. A total of 11 duplicate articles were excluded. After evaluation of the titles and abstracts, 19 articles were selected for full-text evaluation. Of these, one was excluded because it did not estimate the prevalence of Raynaud's phenomenon in the group of workers. In the end, 18 articles met the eligibility criteria and were included in the review (13 cross-sectional studies and 5 cohorts) - Figure 1.

The studies are highly heterogeneous. There are important differences in the analyzed populations, occupations, ways of estimating exposure to risk factors, definitions/evaluations of the Raynaud's phenomenon, and outcomes. All studies discussed exposure to localized vibrations. In 6 of them, the thermal issue was directly or indirectly addressed. No studies have addressed the exposure to vinyl chloride. The main features of the studies are presented in Tables 1 and 2.

\section{DISCUSSION}

The search strategy of this review contemplates three occupational risk factors for Raynaud's phenomenon according to the list of work-related diseas- es (Brazilian Ministry of Health): localized vibrations, cold, and vinyl chloride ${ }^{4}$. Despite the broad scope of the research, there is a marked predominance of the topic "localized vibration of hands and arms" among the articles included. The cold was not addressed as an isolated risk factor in any article, and vinyl chloride was not discussed in any study.

In general terms, the literature review reiterates some expected data such as a higher prevalence of Raynaud's phenomenon among vibratory tool operators compared to non-exposed workers ${ }^{9,13,14}$, an increased prevalence of this event the longer the exposure time to vibration ${ }^{8,21,23}$, as well as among those exposed to higher levels of hand and arm vibration $^{13,17,23}$.

The studies that addressed the thermal issue suggest that the cold environment is an important synergy factor in the emergence of vascular manifestations of vibration syndrome ${ }^{10,12,13}$. In the articles evaluated, temperature measurements were not performed in the workplace, but some studies considered metrological information to estimate exposure to colder environments ${ }^{12,13}$.

In a study with construction electricians ${ }^{12}$, among whom $95 \%$ used vibration tools at work, the

\section{FIGURE 1.}

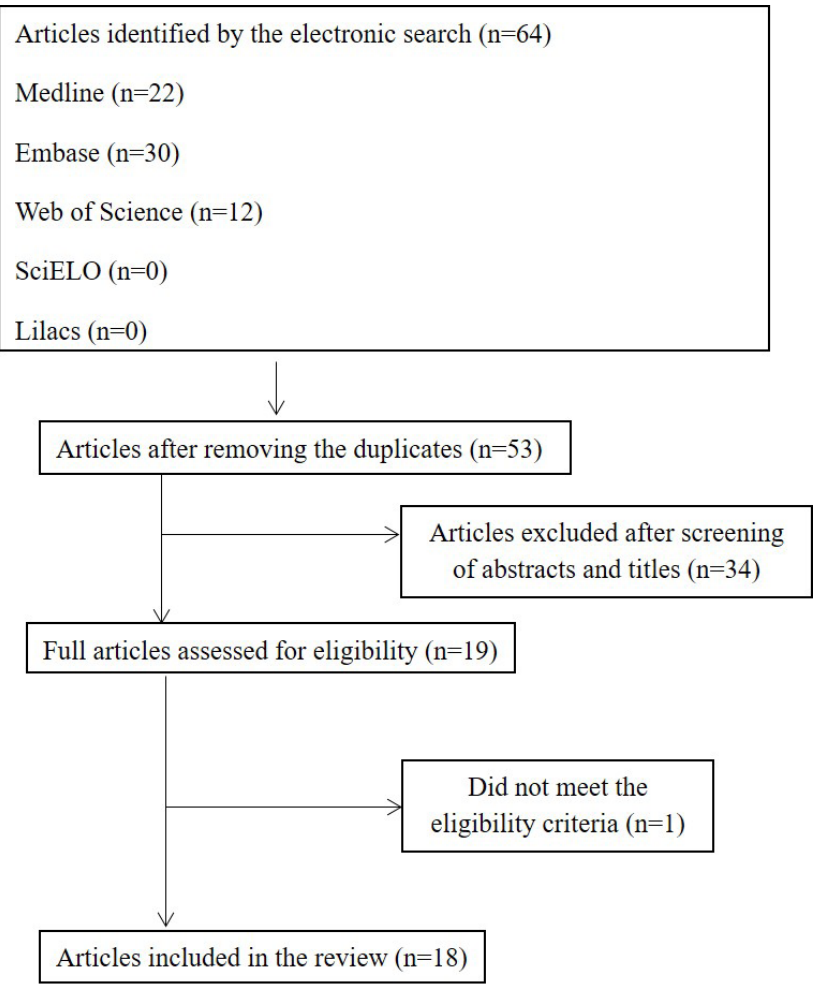


TABLE 1. RAYNAUD PHENOMENON IN WORKERS WITH EXPOSURE TO LOCALIZED VIBRATIONS, LOW TEMPERATURES, OR VINYL CHLORIDE.

\begin{tabular}{|c|c|c|c|c|c|c|}
\hline First author & Year & $\begin{array}{l}\text { Study } \\
\text { design }\end{array}$ & Country & Characteristics (population) & Characteristics (occupation) & Type of exposure \\
\hline Kluger $^{8}$ & 2017 & Transversal & Finland & $\begin{array}{l}1000 \text { people invited by email; } \\
\text { response rate: } 45 \% \text {, } 98 \text { women } \\
\text { and } 350 \text { men }\end{array}$ & $\begin{array}{l}\text { Tattoo artists who are } \\
\text { members of the French Union } \\
\text { of Tattoo Artists }\end{array}$ & Vibration: tattoo gun \\
\hline Pettersson ${ }^{9}$ & 2014 & Transversal & Sweden & $\begin{array}{l}\text { Workers with ONIHL*; received } \\
\text { the questionnaire: } 246 \text { men/78 } \\
\text { women; response rate: } 41 \%\end{array}$ & $\begin{array}{l}\text { Most common occupations: } \\
\text { teachers, military, and welders }\end{array}$ & $\begin{array}{l}\text { Vibration: questions to estimate } \\
\text { minutes/day and years of } \\
\text { exposure. Cold: time outdoors } \\
\text { when working }\end{array}$ \\
\hline Roquelaure ${ }^{10}$ & 2012 & Transversal & France & $\begin{array}{l}3.710 \text { workers, } 2.161 \text { men }(58 \%) \\
\text { and } 1.549 \text { women }(42 \%)\end{array}$ & $\begin{array}{l}\text { Almost all occupations except } \\
\text { farmers, artisans, tenants, } \\
\text { self-employed }\end{array}$ & $\begin{array}{l}\text { Vibration tools ( } \geq 2 \text { hours/day): } \\
460 \text { workers. Cold temperature } \\
<15^{\circ} \mathrm{C} \text { ( } \geq 4 \text { hours/day): } 220 \text { workers }\end{array}$ \\
\hline Aiba ${ }^{11}$ & 2012 & Cohort & Japan & $\begin{array}{l}704 \text { workers ( } 685 \text { men and } 19 \\
\text { women). Mean observation } \\
\text { time: } 10.6 \pm 7.4 \text { years }\end{array}$ & $\begin{array}{l}\text { Workers using an impact } \\
\text { wrench }\end{array}$ & $\begin{array}{l}\text { Vibration: } 8 \text { vibrating tools } \\
\text { selected to be evaluated during } \\
\text { work. Acceleration: } 4.9-22.6 \text { m/ } \\
\text { s2 }\end{array}$ \\
\hline Burström ${ }^{13}$ & 2010 & Transversal & Sweden & $\begin{array}{l}\text { Cases: } 19,251 \text { men exposed } \\
\text { to vibration of hands/arms. } \\
\text { Controls: } 3,350 \text { office workers }\end{array}$ & $\begin{array}{l}\text { Cases: construction workers } \\
\text { with exposure to hand and } \\
\text { arm vibration }\end{array}$ & $\begin{array}{l}\text { Vibration: } 0-5 \text { scale (occupational } \\
\text { hygienists). Cold: local } \\
\text { metrological information }\end{array}$ \\
\hline Bovenzi ${ }^{14}$ & 2010 & Cohort & Italy & $\begin{array}{l}\text { Cases: } 249 \text { workers with } \\
\text { exposure to vibration. Controls: } \\
138 \text { workers without exposure }\end{array}$ & $\begin{array}{l}\text { Forestry workers (chainsaws } \\
\text { with anti-vibration device) } \\
\text { and quarry workers }\end{array}$ & $\begin{array}{l}\text { Vibration: ISO 5349. Estimation of } \\
\text { daily exposure: direct observation } \\
\text { for one week (chronometer) }\end{array}$ \\
\hline Bovenzi ${ }^{15}$ & 2008 & Cohort & Italy & $\begin{array}{l}\text { Cohort of } 128 \text { forestry workers. } \\
\text { At the end of the follow-up, } 57 \\
\text { workers }(44.5 \%) \text { had retired }\end{array}$ & $\begin{array}{l}\text { Forestry workers: chainsaw } \\
\text { operators }\end{array}$ & $\begin{array}{l}\text { Vibration: sample of } 9 \text { chainsaws } \\
\text { during operating conditions as } \\
\text { per ISO } 5349\end{array}$ \\
\hline Bovenzi ${ }^{16}$ & 2008 & Cohort & Italy & $\begin{array}{l}183 \text { forestry workers and } 33 \\
\text { quarry workers completed the } \\
\text { follow-up }\end{array}$ & $\begin{array}{l}\text { Forestry workers: chainsaws. } \\
\text { Quarry workers: tools for } \\
\text { processing marble }\end{array}$ & $\begin{array}{l}\text { Vibration: measurements taken } \\
\text { during tool operating conditions } \\
\text { as per ISO } 5349\end{array}$ \\
\hline Futatsuka ${ }^{18}$ & 2005 & Transversal & Japan & $\begin{array}{l}73 \text { quarry drill operators; } 29 \\
\text { controls: manual tasks in the } \\
\text { same companies }\end{array}$ & $\begin{array}{l}\text { Quarry drill operators (rock } \\
\text { drill) }\end{array}$ & $\begin{array}{l}\text { Vibration: ISO 5349. Acceleration } \\
\text { (drills): } 45-55 \mathrm{~m} / \mathrm{s} 2 ; 160-210 \mathrm{~min} / \\
\text { day. Temp: South of Vietnan } \\
>250 \mathrm{C}\end{array}$ \\
\hline Barregard ${ }^{\mathbf{1 9}}$ & 2003 & Transversal & Sweden & $\begin{array}{l}900 \text { car mechanics received a } \\
\text { questionnaire; } 806 \text { replied }\end{array}$ & Mechanics of cars & $\begin{array}{l}\text { Vibration: working time (average): } \\
12 \text { years. Exposure: } 14 \text { minutes/ } \\
\text { day. Vibration level: } 3.5 \mathrm{~m} / \mathrm{s} 2\end{array}$ \\
\hline Allen ${ }^{20}$ & 2002 & Transversal & Ireland & $\begin{array}{l}\text { Three groups of men ( } 79 \\
\text { riveters, } 52 \text { healthy controls, } \\
\text { and } 79 \text { claimants) }\end{array}$ & $\begin{array}{l}\text { Workers: riveters. Controls: } \\
\text { no vibration. Claimants: yard/ } \\
\text { public services }\end{array}$ & $\begin{array}{l}\text { Vibration: exposure time of } 0.2 \text { - } \\
18 \text { years among riveters and } 1.5 \\
\text { - } 48 \text { years among claimants }\end{array}$ \\
\hline Palmer & 2000 & Transversal & $\begin{array}{l}\text { United } \\
\text { Kingdom }\end{array}$ & $\begin{array}{l}\text { Questionnaires answered by } \\
12.907 \text { people aged } 16-64 \text { years } \\
\text { ( } 6.913 \text { men/5.994 women) }\end{array}$ & $\begin{array}{l}\text { Unspecified, random selection } \\
\text { of record lists }\end{array}$ & $\begin{array}{l}\text { Vibration: exposure assessed by } \\
\text { questionnaire }\end{array}$ \\
\hline Aiba 22 & 1999 & Cohort & Japan & $\begin{array}{l}383 \text { workers (men): use of } \\
\text { impact wrench in electric light } \\
\text { pole factory, } 1982 \text { to } 1999\end{array}$ & $\begin{array}{l}\text { Workers using an impact } \\
\text { wrench }\end{array}$ & $\begin{array}{l}\text { Vibration: ISO } 5349 \text { and JIS } \\
\text { B } 49000 . \text { Exposure: } 102 \text { to } \\
117 \text { minutes/day. Cold: not } \\
\text { characterized }\end{array}$ \\
\hline Palmer ${ }^{23}$ & 1998 & Transversal & England & $\begin{array}{l}153 \text { gas distribution agents } \\
\text { (response rate } 81 \% \text { ). Average of } \\
16 \text { years using vibrating tools }\end{array}$ & $\begin{array}{l}\text { Gas distribution agents } \\
\text { (pneumatic tools) }\end{array}$ & $\begin{array}{l}\text { Vibration: ISO } 5349 . \\
\text { Vibratory tools (time of use - } \\
\text { questionnaire): } 1.2 \text { to } 5.5 \text { hours/ } \\
\text { week (on average) }\end{array}$ \\
\hline Bovenzi24 & 1998 & Transversal & Italy & $\begin{array}{l}\text { Cases: } 822 \text { workers exposed to } \\
\text { vibration, Controls: } 455 \text { healthy } \\
\text { men not exposed }\end{array}$ & $\begin{array}{l}\text { Grinders, mechanics, quarry } \\
\text { drillers, construction/forestry } \\
\text { workers, etc. }\end{array}$ & $\begin{array}{l}\text { Vibration: ISO 5349; } 8.3 \mathrm{~m} / \\
\mathrm{s} 2 \text { (percussion); } 2.8-4.7 \mathrm{~m} / \mathrm{s} 2 \\
\text { (percussion/rotary); }<2 \mathrm{~m} / \mathrm{s} 2 \\
\text { (rotary hand tools) }\end{array}$ \\
\hline Miyashita ${ }^{25}$ & 1998 & Transversal & Japan & $\begin{array}{l}4652 \text { private forestry workers (at } \\
\text { least } 1 \text { medical examination for } \\
V^{\star *} \text { from } 1974 \text { to 1996) }\end{array}$ & $\begin{array}{l}\text { Forestry workers exposed } \\
\text { to hand and arm vibration } \\
\text { (chainsaws) }\end{array}$ & $\begin{array}{l}\text { Vibration: estimation of career } \\
\text { time operating vibratory tools }\end{array}$ \\
\hline
\end{tabular}


TABLE 2. RAYNAUD PHENOMENON IN WORKERS WITH EXPOSURE TO LOCALIZED VIBRATIONS, LOW TEMPERATURE, OR VINYL CHLORIDE: EVALUATION OF THE RAYNAUD PHENOMENON AND OUTCOME.

\begin{tabular}{|c|c|c|}
\hline First author & Evaluation of the Raynaud phenomenon & Outcome \\
\hline Kluger $^{8}$ & $\begin{array}{l}\text { Questionnaire by e-mail. RP*: finger whitening related } \\
\text { to cold. No evaluation was performed by a physician }\end{array}$ & $\begin{array}{l}448 \text { questionnaires: } 30 \text { reported symptoms of } \mathrm{RP}^{*} ; 11 \text { appeared } \\
\text { after the beginning of tattooing activity. Daily work hours: } \\
\text { association with } \mathrm{RP}^{*}\end{array}$ \\
\hline Pettersson ${ }^{9}$ & $\mathrm{RP}^{\star}$ classified by the questionnaire (with image) & $\begin{array}{l}\text { RP }^{*} \text { considered in } 37 \% \text { of those who reported exposure to hand } \\
\text { and arm vibration and in } 15 \% \text { of those who did not report the } \\
\text { exposure }\end{array}$ \\
\hline Roquelaure $^{10}$ & $\begin{array}{l}\text { Doctor asked about RP* features (last } 12 \text { months), } \\
\text { defined as finger whitening episodes triggered by } \\
\text { exposure to cold }\end{array}$ & $\begin{array}{l}87 \text { cases of RP* diagnosed, } 56 \text { (women) and } 31 \text { (men). Female: } \\
\text { association with psychosocial factors. Male: association with } \\
\text { exposure to cold }\end{array}$ \\
\hline Aiba"11 & $\begin{array}{l}\text { Medical evaluation with questions about the signs/ } \\
\text { symptoms related to } \mathrm{RP}^{*} \text { and typical image to aid in } \\
\text { reporting }\end{array}$ & $\begin{array}{l}\text { RP*: } 39 \text { workers during the period. Incidence of RP*: } 6.27 \text { people } \\
\text { per } 1000 \text { individuals-year. Prevalence: } 0.6 \% \text { (1982), } 6.2 \% \text { (1987), } \\
4.9 \% \text { (2008) }\end{array}$ \\
\hline Inaba12 & $\begin{array}{l}\text { Self-administered questionnaire. "White finger in } \\
\text { response to cold environment". No evaluation by a } \\
\text { physician and no picture of RP* }\end{array}$ & $\begin{array}{l}\text { Prevalence of } \mathrm{RP}^{*} \text { among construction electricians: } 43.2 \% \text { (winter) } \\
\text { and } 7.2 \% \text { (summer) }\end{array}$ \\
\hline Burström ${ }^{\mathbf{1 3}}$ & $\begin{array}{l}\text { Self-administered questionnaire. Prevalence of RP* } \\
\text { estimated by the questionnaire, without medical } \\
\text { evaluation }\end{array}$ & $\begin{array}{l}\text { Prevalence of white fingers: } 13.4 \% \text { (hand/arm vibration); } 8.4 \% \\
\text { (controls). Higher odds ratio: intense vibration categories and } \\
\text { workers in the North }\end{array}$ \\
\hline Bovenzi ${ }^{14}$ & $\begin{array}{l}\text { Criterion 1: reliable history (images of RP*). Criterion } 2 \\
\text { (more restrictive): history of "white fingers" and cold } \\
\text { provocation test }\end{array}$ & $\begin{array}{l}\text { Prevalence of RP*: Criterion } 1: 21.7 \% \text { (vibration) and } 7.3 \% \text { (controls). } \\
\text { Criterion } 2: 10.8 \% \text { (vibration) and } 0.7 \% \text { (controls) }\end{array}$ \\
\hline Bovenzi ${ }^{15}$ & $\begin{array}{l}\text { Physical examination; } \mathrm{RP}^{\star} \text { related to occupation if } \\
\text { provoked by cold and first episode after the beginning } \\
\text { of occupational exposure }\end{array}$ & $\begin{array}{l}\text { Prevalence of } \mathrm{RP}^{*} \text { related to vibration (beginning of the study): } \\
26.6 \% ; 11 \text { new cases during the follow-up; cumulative incidence: } \\
11.7 \%\end{array}$ \\
\hline Bovenzi'i6 & $\begin{array}{l}\text { Physical examination; } \mathrm{RP}^{*} \text { related to occupation if } \\
\text { provoked by cold and first episode after the beginning } \\
\text { of occupational exposure }\end{array}$ & $\begin{array}{l}\text { Prevalence of } \mathrm{RP}^{*} \text { related to vibration (beginning of the study): } \\
18.1 \% \text { (forest workers: } 14.8 \% \text {; quarry workers:36.4\%). Incidence:1.7\% } \\
\text { (3 cases) }\end{array}$ \\
\hline Bovenzi ${ }^{17}$ & $\begin{array}{l}\text { Physical examination; } \mathrm{RP}^{\star} \text { related to occupation if } \\
\text { provoked by cold and first episode after the beginning } \\
\text { of occupational exposure }\end{array}$ & $\begin{array}{l}\text { Daily vibration: higher in group } A(4.7 \mathrm{~m} / \mathrm{s} 2) \text { than in group } \mathrm{B}(3.9 \\
\mathrm{m} / \mathrm{s} 2) \text {; no significant difference }\left(R P^{*}\right) \text { between furniture sander } \\
\text { and controls }\end{array}$ \\
\hline Futatsuka ${ }^{18}$ & $\begin{array}{l}\text { Subjective complaints assessed by interview. Peripheral } \\
\text { circulation and neurosensory tests }\end{array}$ & $\begin{array}{l}\text { No workers suffering from "white fingers". Hypoaesthesia, } \\
\text { weakness, and coldness in fingers/hands: significantly higher in the } \\
\text { drill operators }\end{array}$ \\
\hline Barregard ${ }^{19}$ & $\begin{array}{l}\text { Diagnosis based on the history of well-marked pallor } \\
\text { episodes on the fingers or parts of the fingers (induced } \\
\text { by cold) }\end{array}$ & $\begin{array}{l}\text { Estimated prevalence of } \mathrm{RP}^{*} \text { related to vibration: approximately } \\
15 \% \text { among car mechanics }\end{array}$ \\
\hline Allen $^{20}$ & $\begin{array}{l}\text { Questionnaire: medical and occupational history. } \\
\text { Vasospasm: provocative test (cold) and systolic } \\
\text { pressure of the finger }\end{array}$ & $\begin{array}{l}\text { Riveters (6.3\%) and claimants }(83.5 \%) \text { reported } \mathrm{RP}^{*} \text { symptoms. } \\
\text { Positive test for vasospasm (finger cooling): riveters }(30.4 \%) ; \\
\text { claimants }(19 \%)\end{array}$ \\
\hline Palmer ${ }^{21}$ & $\begin{array}{l}\text { Questionnaire considering well-marked alterations of } \\
\text { finger coloration caused by cold conditions }\end{array}$ & $\begin{array}{l}\text { Pallor of the fingers (history): } 14.2 \% \text {. Cold-induced: } 11.8 \% \text {. Clear } \\
\text { demarcation: } 4.6 \% \text {. Time of exposure (vibration): associated with } \\
\text { symptoms }\end{array}$ \\
\hline Aiba 22 & $\begin{array}{l}\text { Questionnaire: medical and occupational history. } \\
\text { Doctor asked about RP*related factors (images of RP*) }\end{array}$ & $\begin{array}{l}\text { Prevalence of } \mathrm{RP}^{\star} \text { related to vibration: } 1.7 \% \text { (1982), 4.86\% (1986), } \\
\text { disappearing in 1994. During the period: preventive measures } \\
\text { introduced }\end{array}$ \\
\hline Palmer ${ }^{23}$ & $\begin{array}{l}\text { Interview with doctor or nurse, questionnaire, physical } \\
\text { examination, and hand immersion test in cold water } \\
\text { ( } 2-80 \text { C for } 4 \text { minutes) }\end{array}$ & $\begin{array}{l}\text { Prevalence of pallor of the fingers: } 24 \% \text {. Risk increased significantly } \\
\text { with the hours of use of vibratory tools and the level of vibration }\end{array}$ \\
\hline Bovenzi $i^{24}$ & $\begin{array}{l}\text { Diagnosis: positive history for pallor episodes involving } \\
\text { at least } 1 \text { finger and occurring after exposure to } \\
\text { localized upper limb vibration }\end{array}$ & $\begin{array}{l}\text { Prevalence of } \mathrm{RP}^{*}: 17.2 \% \text { among workers exposed to vibration, } \\
\text { ranging from } 9.0 \% \text { among grinders to } 51.6 \% \text { among foundry } \\
\text { workers }\end{array}$ \\
\hline Miyashita ${ }^{25}$ & Medical evaluation records & $\begin{array}{l}\text { Prevalence of workers who complained of "white fingers" induced } \\
\text { by vibration: } 25.9 \% \text { (1978), } 25.7 \% \text { (1988) and } 15.1 \% \text { (1996) }\end{array}$ \\
\hline
\end{tabular}

$\mathrm{RP}^{*}=$ Raynaud phenomenon

prevalence of subjective symptoms of Raynaud's phenomenon was found in $43.2 \%$ of them during the winter (temperature of $5.5^{\circ} \mathrm{C}$ on average) and only in $7.2 \%$ during the summer (temperature of $24.4^{\circ} \mathrm{C}$ on average). A Swedish study ${ }^{13}$ in which the contrast of the cold environment was made by choosing a northern and a southern region of the country, suggested that the factors mainly related to the Raynaud's phenomenon were the two most intense categories of exposure to vibration in workers living farther north (colder weather) compared to the south. 
Regarding the manifestations of hand-arm vibration syndrome, it is known that neurosensory alterations and vasospastic disease can coexist or progress independently ${ }^{5}$. A Japanese study ${ }^{18}$ evaluating quarry workers (drill operators) from southern Vietnam did not identify cases of Raynaud's phenomenon. However, the prevalence of peripheral neurologic symptoms such as hypoaesthesia and weakness of the hands were significantly higher among the drill operators than in the controls. The hypothesis raised by the authors is that cold is an essential factor to trigger vascular manifestations of hand-arm vibration syndrome, and the workers evaluated did not develop them because they remained in environments with temperatures higher than $25^{\circ} \mathrm{C}$ throughout the year. In this way, the authors of this study suggest that, in a tropical environment, workers exposed to high levels of vibration could develop a dominant neurosensory form of hand-arm vibration syndrome, reinforcing the theory that circulatory and neuropathic symptoms may be independent ${ }^{18}$.

Another issue that deserves attention when evaluating the results of the studies included in this review refers to the methodological limitations of certain forms of research. Some studies only used information obtained through questionnaires to define the presence of Raynaud's phenomenon related to vibration ${ }^{8,9,12,13}$. However, the self-reported symptoms alone may not be sufficiently specific to assess whether Raynaud's phenomenon is primary or secondary, and as a result, there may have been incorrect classification in some cases. Likewise, the quantification of the duration of exposure to hands and arms vibration is not an easy task and is subject to recall biases when estimated through questionnaires or even by direct interview ${ }^{9}$.

Questionnaire responses about symptoms suggestive of Raynaud's phenomenon may be influenced by the context in which they are obtained. An Irish study $^{20}$ comparing riveters to a group of claimants for vibration-related injury showed that $6.3 \%$ of riveters and $83.5 \%$ of claimants reported symptoms of Raynaud's phenomenon. However, 30.4\% of the riveters and only $19 \%$ of the claimants had a positive test for vasospasm after cooling the finger at $10^{\circ} \mathrm{C}$ for 5 minutes. The authors argued that only the lack of sensitivity and specificity of the cold provocation test would not explain the large discrepancy between the riveters and the claimants ${ }^{20}$. Thus, some contexts could underestimate, and others overestimate the symptoms.

In order to reduce the prevalence of Raynaud's phenomenon by localized upper limb vibration, measures such as limiting working hours with vibrating tools, using anti-vibration technology, and maintaining the working environment warm are performed ${ }^{22}$. In a Japanese study, technical improvements in tool motors with the introduction of anti-vibration mechanisms dramatically reduced the vibration transmitted to the hands of workers using impact wrenches ${ }^{22}$. In this study, the prevalence of Raynaud's phenomenon among workers was $4.86 \%$ in 1986 and gradually declined until disappearing in 1994. During this period, impact wrenches with anti-vibration mechanisms and measures to regulate the environment and protect workers from the cold were introduced (curtains to protect against outside cold, hand washing with warm water and impact wrench with heated handle) ${ }^{22}$.

Articles exploring vinyl chloride as an occupational risk factor for Raynaud's phenomenon were not found in our search. This fact is probably due to two reasons. The first to be considered is that vinyl chloride disease is a rare event, and most of the studies are case reports or cases series, which were not considered in our search strategy. The second, and possibly even more important, is related to the fact that our electronic search was restricted to the last 20 years. Since 1979, vinyl chloride has been classified as carcinogenic to humans ${ }^{7}$, and industries have made interventions to reduce the concentration of this substance in occupational air drastically. This allowed "vinyl chloride disease" to have only a historical significance today.

\section{CONCLUSION}

Localized vibrations of the upper limbs, low temperatures, and vinyl chloride are considered occupational risk factors for the development of Raynaud's phenomenon. There is a higher prevalence of Raynaud's phenomenon among vibratory tool operators compared to non-exposed workers. The higher the level of vibration and the time of exposure to it, the greater the risk of developing the disease. Cold is a triggering and aggravating factor of Raynaud's phenomenon and plays an important role in the onset of vascular manifestations of handarm vibration syndrome. The reduction of the time 
using vibrating tools, the acquisition of equipment with anti-vibration technology, and the adoption of measures to protect workers from the cold environment should be considered to reduce the prevalence of work-related Raynaud's phenomenon.

\section{Contributions by the authors}

Author's contributions: RAC: conception, data acquisition, and manuscript writing.

RMA: conception, data acquisition, and manuscript writing.

Acknowledgements: Not applicable.

\section{RESUMO}

OBJETIVO: Realizar um estudo de revisão dos artigos que avaliaram a prevalência do fenômeno de Raynaud de origem ocupacional.

MÉTODOs: A busca pelos artigos foi realizada nas bases de dados Medline (via PubMed), Embase, Web of Science, Scientific Eletronic Library Online (SciELO) e Literatura Latino-Americana e do Caribe em Ciências da Saúde (Lilacs).

RESULTADOS: Sessenta e quatro artigos foram obtidos a partir da busca eletrônica, dos quais 18 cumpriram os critérios de elegibilidade. Todos os estudos discutiram sobre a exposição a vibrações localizadas em membros superiores. Em seis deles, a questão térmica foi direta ou indiretamente abordada. Nenhum estudo abordou a exposição ao cloreto de vinila.

CONCLUSÃo: De maneira geral, constatou-se maior prevalência do fenômeno de Raynaud entre operadores de ferramentas vibratórias em comparação aos não expostos, com aumento do número de casos quanto maior o nível de vibração e tempo de exposição. O frio é fator desencadeante e agravante do fenômeno de Raynaud e parece exercer papel importante para o surgimento das manifestações vasculares da sindrome de vibração de mãos e braços.

PALAVRAS-CHAVE: Doença de Raynaud. Doenças vasculares periféricas. Vibração. Cloreto de vinil. Temperatura baixa.

\section{REFERENCES}

1. Wigley FM, Flavahan NA. Raynaud's phenomenon. N Engl J Med. 2016;375(6):556-65.

2. Maverakis E, Patel F, Kronenberg DG, Chung L, Fiorentino D, Allanore Y, et al. International consensus criteria for the diagnosis of Raynaud's phenomenon. J Autoimmun. 2014;48-49:60-5.

3. Wigley FM, Herrick AL, Flavahan NA. Raynaud's phenomenon: a guide to pathogenesis and treatment. New York: Springer-Verlag; 2015.

4. Brasil. Ministério da Saúde; Organização Pan-Americana da Saúde. Doenças relacionadas ao trabalho: manual de procedimentos para os serviços de saúde. Braślia: Ministério da Saúde; OPAS; 2001. 508p.

5. Palmer KT, Bovenzi M. Rheumatic effects of vibration at work. Best Pract Res Clin Rheumatol. 2015;29(3):424-39.

6. World Health Organization (WHO). Vinyl chloride. Environmental health criteria 215. Geneva: World Health Organization; 1999.

7. International Agency for Research on Cancer (IARC). Vinyl chloride, polyvinyl chloride and vinyl chloride-vinyl acetate copolymers. In: IARC monographs on the evaluation of carcinogenic risk of chemicals to humans. Lyon: International Agency for Research on Cancer; 1979 p.377-438.

8. Kluger N. National survey of health in the tattoo industry: observational study of 448 French tattooists. Int J Occup Med Environ Health. 2017;30(1):111-20.

9. Pettersson H, Burström L, Nilsson T. Raynaud's phenomenon among men and women with noise-induced hearing loss in relation to vibration exposure. Noise Health. 2014;16(69):89-94.

10. Roquelaure $Y, H a$ C, Le Manac'h AP, Bodin I, Bodere A, Bosseau C, et al. Risk factors for Raynaud's phenomenon in the workforce. Arthritis Care Res (Hoboken). 2012;64(6):898-904

11. Aiba Y, Yamamoto K, Ohshiba S, Ikeda K, Morioka I, Miyashita K, et al. A longitudinal study on Raynaud's phenomenon in workers using an impact wrench. J Occup Health. 2012;54(2):96-102.

12. Inaba R, Mirbod SM. Subjective musculoskeletal symptoms in winter and summer among indoor working construction electricians. Ind Health. 2010;48(1):29-37.

13. Burström L, Järvholm B, Nilsson T, Wahlström J. White fingers, cold environment, and vibration-exposure among Swedish construction workers. Scand J Work Environ Health. 2010;36(6):509-13.
14. Bovenzi M. A prospective cohort study of exposure-response relationship for vibration-induced white finger. Occup Environ Med. 2010;67(1):38-46.

15. Bovenzi M. A follow up study of vascular disorders in vibration-exposed forestry workers. Int Arch Occup Environ Health. 2008;81(4):401-8.

16. Bovenzi M, D'Agostin F, Rui F, Negro C. A longitudinal study of finger systolic blood pressure and exposure to hand-transmitted vibration. Int Arch Occup Environ Health. 2008;81(5):613-23.

17. Bovenzi M, Della Vedova A, Nataletti P, Alessandrini B, Poian T. Work-related disorders of the upper limb in female workers using orbital sanders. Int Arch Occup Environ Health. 2005;78(4):303-10.

18. Futatsuka M, Shono M, Sakakibara H, Quoc Quan P. Hand arm vibration syndrome among quarry workers in Vietnam. J Occup Health. 2005;47(2):165-70.

19. Barregard L, Ehrenström L, Marcus K. Hand-arm vibration syndrome in Swedish car mechanics. Occup Environ Med. 2003;60(4):287-94.

20. Allen JA, McGrann S, McKenna KM. Use of a questionnaire screening for vibration white finger in a high risk industrial population. Int Arch Occup Environ Health. 2002;75(1-2):37-42.

21. Palmer KT, Griffin MJ, Syddall H, Pannett B, Cooper C, Coggon D. Prevalence of Raynaud's phenomenon in Great Britain and its relation to hand transmitted vibration: a national postal survey. Occup Environ Med. 2000;57(7):448-52.

22. Aiba Y, Ohshiba S, Ishizuka H, Sakamoto K, Morioka I, Miyashita K, et al. A study on the effects of countermeasures for vibrating tool workers using an impact wrench. Ind Health. 1999;37(4):426-31.

23. Palmer K, Crane G, Inskip H. Symptoms of hand-arm vibration syndrome in gas distribution operatives. Occup Environ Med. 1998;55(10):716-21.

24. Bovenzi M. Vibration-induced white finger and cold response of digital arterial vessels in occupational groups with various patterns of exposure to hand-transmitted vibration. Scand I Work Environ Health. 1998;24(2):138-44.

25. Miyashita K, Tomida K, Morioka I, Sasaki T, Iwata H. Health surveillance of forestry workers exposed to hand-arm vibration in Wakayama from 1974 to 1996. Ind Health. 1998;36(2):160-5. 